\title{
Intramammary infections and milk leakage following gradual or abrupt cessation of milking
}

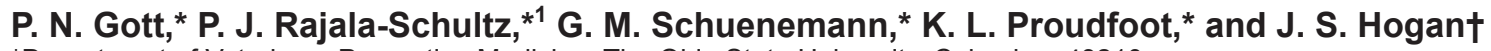 \\ *Department of Veterinary Preventive Medicine, The Ohio State University, Columbus 43210 \\ †Department of Animal Sciences, Ohio Agricultural Research and Development Center, The Ohio State University, Wooster 44691
}

\begin{abstract}
The objective of this study was to evaluate the effect of milking cessation method (abrupt or gradual) and daily milk yield before dry-off on milk leakage following dry-off and intramammary infections (IMI) at calving. Data from 1,086 quarters of 285 cows from 5 Ohio dairy herds were analyzed. All cows that were due to be dried off within a week were assigned to the same study group to facilitate management. Abrupt-cessation cows kept the farm's regular milking schedule through dryoff, and gradual-cessation cows were milked once daily for the final week of lactation. Aseptic technique was used to collect quarter foremilk samples at the time of enrollment ( 7 to $14 \mathrm{~d}$ before expected dry-off), the final milking before dry-off (D-O), and within $7 \mathrm{~d}$ of calving. Cows in the gradual-cessation group were observed for milk leakage during the period of once-daily milking. In the only herd that did not use internal teat sealants at dry-off, milk leakage after dry-off was recorded in both abrupt and gradual groups. Gradual cessation decreased milk production by $33.4 \%$ during the final week of lactation, causing milk yield at D-O to be lower for these cows compared with abrupt-cessation cows (13.2 vs. $19.8 \mathrm{~kg} / \mathrm{d}$, respectively). Logistic regression models were used to model the probability of a quarter being infected at calving with any pathogen, accounting for clustering of quarters within cows and cows within herds. The final model investigating the probability of IMI at calving was stratified by parity of cows at the time of dry-off (primiparous and multiparous). Among quarters of cows that ended their first lactation, abrupt cessation of milking before dry-off and milk leakage after dry-off were associated with an increased risk of IMI at calving. Among quarters of multiparous cows, on the other hand, gradual cessation of milking before dryoff, presence of IMI at D-O, and thrice-daily milking during lactation increased the odds of IMI at calving.
\end{abstract}

Received September 3, 2015.

Accepted January 6, 2016.

${ }^{1}$ Corresponding author: paivi.rajala-schultz@helsinki.fi
These results indicate that implementation of differing management practices near dry-off for different parity groups may improve mammary health within a herd. Key words: milk cessation method, dry-off, intramammary infection, milk leakage

\section{INTRODUCTION}

Mastitis causes significant economic losses for producers (Seegers et al., 2003) and is often caused by bacterial IMI. For dairy cows, the dry period is crucial for good udder health and optimal productivity in the subsequent lactation (Neave et al., 1950; Natzke et al., 1972; Eberhart, 1986). The dry period provides producers an opportunity to treat existing IMI without losses associated with discarded milk due to antimicrobial treatment. However, the periods immediately following dry-off and before calving are associated with an increased susceptibility to new IMI (Neave et al., 1950; Oliver and Mitchell, 1983; Smith et al., 1985). Over $50 \%$ of cases of environmental mastitis that occur during the first $100 \mathrm{~d}$ in milk are acquired during the dry period (Bradley and Green, 2004), and IMI that arise during the dry period are likely to cause clinical mastitis during the following lactation (Bradley and Green, 2000,2001 ). Therefore, it is critical to develop management strategies around dry-off, including methods for the cessation of milking, that reduce disease risk and increase productivity.

Multiple studies of milking cessation method were conducted during the first half of the twentieth century when cows produced substantially less milk than today's average dairy cow (Wayne et al., 1933; Neave et al., 1950; Oliver et al., 1956a). Two of the methods studied were abrupt cessation and gradual cessation (Wayne and Macy, 1933; Espe and Smith, 1952; Oliver et al., 1956b). Abrupt cessation or "stop" milking is when normal daily milking is discontinued on a set day, often based on an expected calving date and a targeted dry period length. Gradual cessation of milking (also referred to as intermittent milking or reduced milking frequency) involves cows being weaned from milking 
over a period of days or weeks. The above-mentioned studies followed different reduced milking frequencies of variable duration and called these methods "gradual cessation" of milking. A more recent study used oncedaily milking for the final week of lactation to achieve gradual cessation of milking (Oliver et al., 1990).

In a study from the 1950s, uninfected quarters of cows that were dried off abruptly had a significantly higher incidence of new infections than uninfected quarters dried off via gradual cessation of milking over either a 14-d or 28-d period (Oliver et al., 1956a). A subsequent study reported that once production had decreased to $4.5 \mathrm{~kg} / \mathrm{d}$, milking could safely be stopped and that gradual cessation was an effective way to decrease milk yield before dry-off (Oliver et al., 1956b). Later reports suggested that gradual cessation of milking was beneficial in herds where antimicrobial dry-cow therapy was not used, but either abrupt or gradual cessation were satisfactory methods to dry cows off if cows were treated with intramammary antimicrobials (Natzke et al., 1975). A more recent study reported the greatest decrease in IMI from dry-off to calving in quarters of cows dried off via gradual cessation, with or without a ration change, during the last week of lactation (Oliver et al., 1990). Similarly, Newman et al. (2010) reported that gradual cessation of milking during the final week of lactation significantly reduced milk yield, and increased milk yield at dry-off was associated with an increased risk of IMI at calving among quarters that were uninfected at dry-off. Another study, in which milking frequency before dry-off was not manipulated, reported that for every 5 -kg increase in milk yield at dry-off above $12.5 \mathrm{~kg}$, the odds of a cow having an environmental IMI at calving increased by $77 \%$ (Rajala-Schultz et al., 2005). These studies highlight the importance of the relationship between milking cessation method, milk yield at dry-off, and mammary health during the dry period and following parturition.

Intramammary pressure increases due to accumulation of milk in the udder between normal milkings (Rovai et al., 2007), during periods of reduced milking frequency (Tucker et al., 2009), and following dry-off (Schukken et al., 1993; Tucker et al., 2009); this pressure can cause milk to leak from the teat canal ("milk leakage"). Milk leakage during various stages of lactation has been associated with an increased risk for clinical mastitis (Schukken et al., 1993; Elbers et al., 1998; Waage et al., 2001). Approximately $30 \%$ of cows leaked milk during the week following dry-off, and the risk of clinical mastitis later in the dry period was 4 times greater for cows that leaked milk after dry-off than for cows that did not leak (Schukken et al., 1993). Other studies that have investigated milk leakage observed cows around the time of parturition (Waage et al., 2001) or during lactation (Schukken et al., 1990; Elbers et al., 1998) and looked for associations with clinical mastitis.

Despite the previous research indicating that gradual cessation of milking is beneficial to udder health (Oliver et al., 1956a; Oliver et al., 1990), 89.8\% of US dairy cows are abruptly dried off according to estimates from the National Animal Health Monitoring System (NAHMS) Dairy 2014 study (Lombard et al., 2015). Determining the optimal cessation method and other quarterand cow-level factors that are associated with good udder health after calving is critical for maintaining productivity and animal welfare in dairy herds. Thus, the objective of the current study was to assess the effect of milking cessation method and daily milk yield before dry-off on milk leakage following dry-off and IMI at calving in today's high-producing dairy cows. The hypothesis was that gradual cessation of milking would decrease milk yield before dry-off, reduce milk leakage after dry-off, and lead to fewer IMI at calving.

\section{MATERIALS AND METHODS}

\section{Study Population}

All procedures used in the present study were approved by The Ohio State University Institutional Animal Care and Use Committee. Five Ohio dairy herds were included in this study. Four herds comprised Holstein cows and one herd was exclusively Jersey cows. Herds were required to be enrolled in the DHIA testing program to participate in the study. The willingness of the producers to follow study protocols was also a prerequisite for inclusion in the study. Dry-off dates were based on breeding date and the individual herd's desired dry period length, which varied among herds, ranging between 45 and $60 \mathrm{~d}$. All herds dried cows off abruptly once a week as their normal dry-off protocol. After the final milking, all quarters of cows were treated with a commercially available antimicrobial labeled for use in nonlactating cows, according to each herd's standard protocols. No alterations were made to the diet during the study period, so all cows remained on their farm's normal lactating ration for the final week of lactation.

Cows were enrolled and data were collected between May 2012 and October 2014. Clinically healthy cows were enrolled 7 to $14 \mathrm{~d}$ before their expected dry-off date, which was based on expected calving date and the farm's goal dry-period length. All cows dried off in the same week were assigned to the same group to make management of the cows easier for the herd personnel. In each herd, the first set of cows was assigned to the abrupt cessation group and thereafter group assign- 
ment alternated weekly between gradual and abrupt cessation groups. Cows were enrolled on the study only once, even if they were dried off more than once during the study period. From each herd, cows were enrolled during different seasons of the year.

Abrupt-cessation cows maintained their farm's regular milking schedule until the last day of lactation, whereas gradual-cessation cows were milked once daily for the final week of lactation. Gradual-cessation cows were housed and managed according to facility and labor confines in each of the 5 herds. One herd on the study was a small tiestall operation and milked cows using a bucket milker at their stall. Three herds were able to separate gradual-cessation cows from the main milking herd and only allowed the cows to go through the milking parlor once daily during the final week of lactation. On the last farm, all cows went through the parlor during every milking, but cows in the gradual-cessation group were only milked once per day according to the study protocol. Gradual-cessation cows were identified with brightly colored leg bands on one hind leg so farm personnel knew to milk those cows only once daily during the final week of lactation. Participants were provided a small monetary incentive for every cow enrolled in the gradual cessation group to compensate for lost saleable milk during the study intervention.

Sample size calculation for the study was based on an assumption of approximately $20 \%$ of quarters being infected at calving and gradual cessation of milking reducing IMI prevalence at calving by $50 \%$. To detect such a difference, 219 quarters per milk cessation method would be needed, which translated to approximately 55 cows enrolled into each group. This minimum sample size was obtained, leaving room to adjust for the clustered data structure and potential confounding factors in the modeling.

\section{Sample Collection and Milk Microbiology}

At the time of enrollment (PRE) and at the final milking before dry-off (D-O), quarter foremilk samples were collected using aseptic technique by study personnel from all study cows. Aseptic technique was also used to collect quarter foremilk samples within $7 \mathrm{~d}$ of calving (CALV) either by the study personnel or farm employees. Study investigators trained farm employees on the use of aseptic technique to collect milk samples by both discussing and demonstrating proper sample collection procedures. Printed copies of the National Mastitis Council (NMC) Procedures for Collecting Milk Samples (NMC, 2004) were also left on each farm for employees to reference when study personnel were not present. If collected by the farm personnel, milk samples were kept frozen on the farm until the next visit by the investigators, when samples were transported on ice to the laboratory for microbiological culture.

Milk samples collected by study personnel were transported to the laboratory on ice and frozen at $-20^{\circ} \mathrm{C}$ for at least $24 \mathrm{~h}$ before microbiological culture. Milk samples were examined according to NMC guidelines (NMC, 2004). Ten microliters (0.01 mL) of milk from each quarter sample was plated onto both $5 \%$ sheep's blood agar (Remel Inc., Lenexa, KS) and MacConkey agar (Remel Inc.). Plates were incubated at $37^{\circ} \mathrm{C}$ and read at 24 and $48 \mathrm{~h}$. Infection status determinations were based on the combination of colony count, colony morphology, Gram stain reaction, and biochemical testing.

A quarter was considered to have an IMI when 10 or more colonies $(1,000 \mathrm{cfu} / \mathrm{mL})$ of similar morphology were isolated (Andersen et al., 2010), except for contagious major pathogens (Staphylococcus aureus and Streptococcus agalactiae), for which growth of one colony was considered an IMI. Isolation of 3 or more colony morphologies was considered contamination. At each sampling, quarters were categorized as having a minor infection (CNS or Corynebacterium spp.), a major infection (all other pathogens), or uninfected per definitions given above. Mixed infections (2 different morphologies per quarter) were counted only as a single infection for the data analyses. Mixed infections were categorized as a major infection if either isolated organism was identified as a major pathogen and as a minor infection if both organisms were minor pathogens.

Quarters were categorized as cured, persistent, or having a new IMI based on infection status at D-O and CALV. An IMI was considered cured when a specific pathogen was isolated as causing an IMI at D-O, but that same pathogen was not isolated at CALV. The presence of the same pathogen at D-O and again at CALV was considered a persistent IMI. New infections at CALV were considered when an uninfected quarter at D-O had an IMI at CALV or when an infected quarter had a different pathogen isolated at CALV from the pathogen isolated at D-O.

\section{Milk Yield}

Four herds included in these analyses had milk meters in their milking parlors and used parlor-specific systems and software to record milk yields for individual cows during each milking. Milk yield data for all study cows were obtained via farm computers during the study period. In the final herd enrolled on the study, cows were housed in a tiestall barn and the producer measured and recorded milk yields manually during the last days of lactation during the study period. Milk yields from 
individual milkings were combined to represent daily milk yields at the cow level $(\mathrm{kg} / \mathrm{d})$. The PRE milk yield used in the analyses was an average of cow-level milk yields from d 8 and 9 before dry-off. The D-O milk yield was an average of cow-level milk yields from $d 2$ and 3 before dry-off.

\section{Milk Leakage}

Gradual Cessation. Cows undergoing gradual cessation of milking were observed for milk leakage once daily on $\mathrm{d} 1,2$, and 4 after the milking intervention began by one investigator (P. N. G.), who walked through the pen of cows and observed the study animals visually for 10 to $15 \mathrm{~s}$ each. Cows were observed at a time when they would have normally been milked without the trial intervention. Milk leakage was recorded as yes or no at the quarter level. Occasionally, milk was puddled underneath a cow but no quarters were actively leaking. When the specific quarter(s) leaking could not be discerned, all quarters of that cow were marked as leaking that day.

After Dry-Off. After dry-off, cows in both the abrupt and gradual cessation treatments from one herd were monitored for milk leakage once daily on d 1, 2, and 4 after dry-off, as described above. The remaining 4 herds in the study were not used for this measurement because they used an internal teat sealant (ITS) following administration of intramammary antibiotics at dry-off, which was expected to block any milk from leaking.

\section{Statistical Analysis}

Cows with unknown IMI status (missing or contaminated samples) for 2 or more different quarters were excluded completely from analysis. Single quarters that were dead (non-functional), had contaminated samples, or otherwise had missing IMI status were not used in the analyses, but the data from the other 3 quarters from those cows were included. For the analysis, cows were dichotomized into 2 parity groups; primiparous (ending first lactation at the time of milk cessation intervention) versus multiparous (ending second or greater lactation at the time of milk cessation intervention).

Descriptive statistics were calculated to summarize the data. Milk yields at PRE and D-O were initially compared within and between study groups at both time points with $t$-test (or paired $t$-test, as needed). The overall proportion of quarters infected at PRE and D-O was compared using chi-square test (SAS Institute Inc., Cary, NC), and IMI status at each time point was compared within and between the study groups. No significant differences were found in IMI status from PRE to D-O $(P>0.5)$ in either study group and, thus, IMI at D-O was determined to best represent IMI status before dry-off. If cows had missing or contaminated quarter samples at D-O but complete IMI status data from PRE, then for those cows, D-O culture results were replaced with PRE results for all 4 quarters and these were used in the final analyses denoted as D-O IMI status.

The GLIMMIX procedure in SAS (version 9.3; SAS Institute Inc.) with a logit link and binomial error distribution was used to model the probability of a quarter being infected (yes/no) at calving with any pathogen. The compound symmetry covariance structure was used to account for clustering of quarters within cows. The main variables of interest were milk cessation method (gradual vs. abrupt) and average daily milk yield at D-O. Other potential predictors, which were first tested in univariable models, included quarter IMI status at D-O (major, minor, uninfected), parity at D-O (primiparous vs. multiparous), season at D-O, milking frequency (the farm's normal milking schedule; either $2 \times$ or $3 \times$ ), whether any quarters of the cow were observed leaking milk after D-O (yes, no, ITS used), ITS used at dry-off (yes vs. no), days in milk at D-O, length of the dry period, and whether gradual-cessation cows were only sent to the milking parlor once daily during the once-daily milking period (sorted or housed separately from main milking herd vs. went through parlor at every milking but only milked once daily). Herd was also tested as a fixed effect and a random effect during the modeling process. Additionally, an interaction term between herd and milk cessation method was considered for inclusion in the models. In the final models, herd was included as a random effect.

Initial univariable screening was performed to identify potential predictors of quarter-level IMI status at CALV. All variables associated with quarter-level IMI status at CALV with $P$-value $<0.25$ were included in a full model. Nonsignificant variables were eliminated one at a time, starting with the least significant one, until all variables remaining in the model were significant with $P<0.05$. To evaluate whether a variable was a confounder between CALV IMI status and milk cessation method and should be kept in the model, the change in the coefficient of milk cessation method was calculated after the variable in question had been dropped from the model. Any variable that induced a change $>10 \%$ was kept in the model. Biologically relevant 2-way interactions between main effects in the final model were also investigated.

Because the initial modeling revealed a highly significant $(P=0.0002) 2$-way interaction between milk cessation method and parity group, the model investi- 
Table 1. Descriptive statistics for herds enrolled in a study investigating the effect of milk cessation method at the end of lactation on IMI status at calving

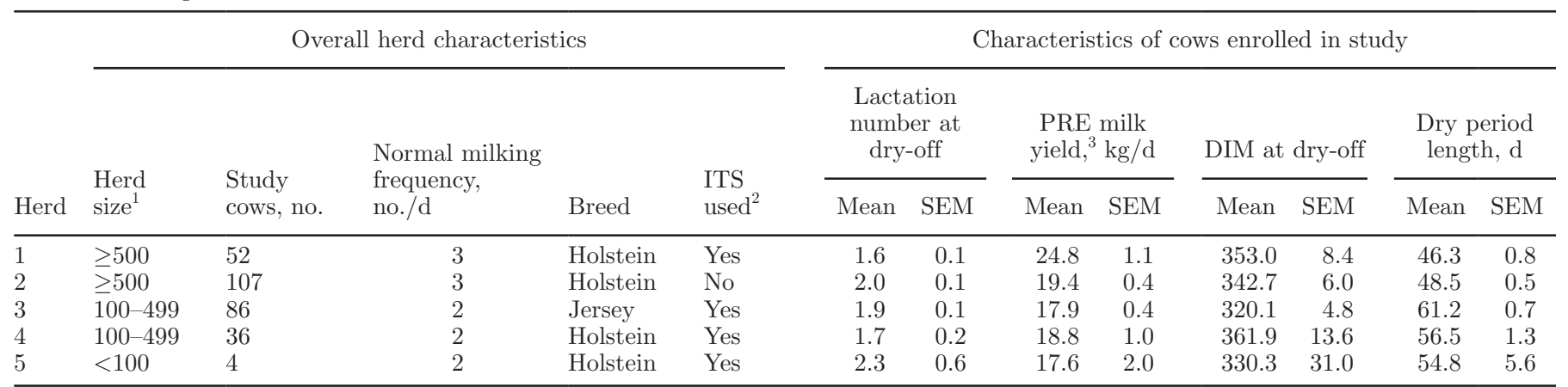

${ }^{1}$ Herd size represents the average number of cows in milk within the herd during the study period.

${ }^{2}$ Whether herds used internal teat sealant (ITS) at dry-off.

${ }^{3} \mathrm{PRE}$ milk yield is the average of individual cow milk yields from d 8 and 9 before dry-off of all study cows within a herd.

gating the probability of a quarter being infected with any pathogen at calving was stratified by parity group. Again, in these parity-specific models, nonsignificant variables were eliminated one at a time, starting with the least significant one, until all variables remaining in the model were significant with $P<0.05$. Potential confounding factors were tested as stated above.

Additionally, the probability that cows would be observed leaking milk during once daily milking was modeled with a similar approach. Only gradual-cessation cows were used in these analyses. The probability that cows would leak milk after dry-off was also modeled with a similar approach. Only cows not infused with an ITS at dry-off were used in the after dry-off leakage analyses. Therefore, the model investigating milk leakage following dry-off was developed using observations from a single herd. Milk cessation method was forced into the model as the main variable of interest. Univariable testing of parity group as a predictor of milk leakage revealed that, both during once-daily milking and following dry-off, cows ending their first and second lactations did not differ significantly from each other in regard to the occurrence of milk leakage, but these younger cows had significantly different odds of milk leakage from older cows. Therefore, parity groups were categorized as cows ending their first or second lactation versus cows ending their third or greater lactation in both milk leakage models.

\section{RESULTS}

\section{Descriptive Statistics}

Study Population. Three hundred sixteen cows were enrolled on the study. Cows with a dry period $<30 \mathrm{~d}$ or $\geq 80 \mathrm{~d}$ were removed from the data set $(\mathrm{n}=$
5). Cows with unknown IMI status (missing or contaminated samples) for 2 or more different quarters were excluded completely from the analysis $(\mathrm{n}=26)$. Single quarters that were dead (nonfunctional), contaminated, or otherwise missing IMI status were not used in the analyses ( $\mathrm{n}=54$ quarters), but the data from the other 3 quarters of those cows were included. Thus, 285 cows (145 gradual cessation; 140 abrupt cessation) and 1,086 quarters (542 gradual cessation; 544 abrupt cessation) from 5 herds were included in the analyses. The study included 142 cows (544 quarters) ending their first lactation (primiparous) and 143 cows (542 quarters) ending their second or greater lactation (multiparous), evenly distributed into both treatment groups. Descriptive statistics characterizing the study herds and study groups are presented in Table 1 and Table 2, respectively.

Milk Yield by Milk Cessation Group. Average daily milk yield from d 8 and 9 before dry-off (PRE) was not significantly different $(P=0.756)$ between the gradual- and abrupt-cessation groups (mean \pm SEM; $19.8 \pm 0.4$ vs. $20.0 \pm 0.5 \mathrm{~kg} / \mathrm{d}$, respectively, Figure 1). Gradual milk cessation, however, significantly decreased the milk yield from PRE to D-O on average by $6.6 \mathrm{~kg}$ $(P<0.0001)$. This also caused milk yields at $\mathrm{D}-\mathrm{O}$ to be lower for gradual- compared with abrupt-cessation cows $(P<0.0001$, Figure 1$)$. On average, once-daily milking reduced daily milk yield by $33.4 \pm 1.5 \%$. In the abrupt-cessation group, milk yield decreased on average $4.3 \pm 1.4 \%$ during the final week of lactation.

Milk Yield by Parity Group. Although milk yields at PRE were not different between the milk cessation groups, PRE milk yields were significantly different $(P$ $=0.004$ ) between primiparous and multiparous cows $(20.8 \pm 0.5$ vs. $18.9 \pm 0.5 \mathrm{~kg} / \mathrm{d}$, respectively). Milk yields were also significantly different between parity 


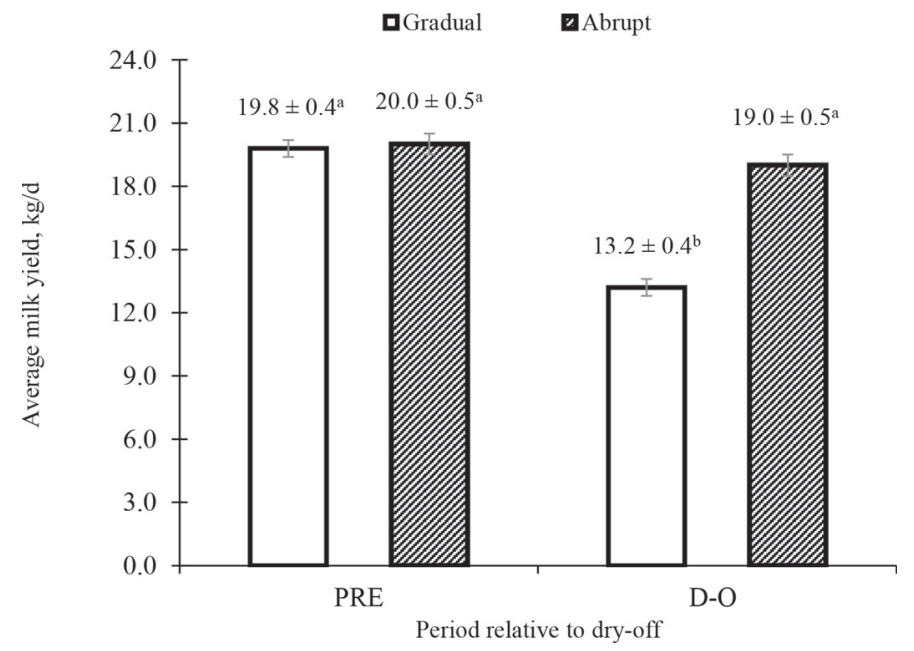

Figure 1. Daily milk yields for gradual and abrupt milk cessation groups, presented as mean \pm SEM for PRE (average milk yield from d 8 and 9 before dry-off; before study intervention) and for D-O (average milk yield from d 2 and 3 before dry-off). Gradual-cessation cows were milked once daily for the final week of lactation and then dried off, whereas abrupt-cessation cows kept their farm's normal milking schedule until dry-off. Significant differences in milk yields between study groups and between time points within groups are denoted by different superscript letters $(P<0.0001)$.

groups at D-O, independent of milk cessation method (primiparous: $16.8 \pm 0.5 \mathrm{~kg} / \mathrm{d}$; multiparous: $15.3 \pm 0.5$ $\mathrm{kg} / \mathrm{d} ; P=0.035)$.

IMI by Milk Cessation Method. The results of the bacterial cultures from quarter-level milk samples at PRE, D-O, and CALV by milk cessation method are presented in Table 3. No significant differences were found in quarter-level IMI prevalence at $\operatorname{PRE}(P=$ $0.102)$, D-O $(P=0.282)$, or CALV $(P>0.5)$ between the abrupt- and gradual-cessation cows (Table 3 ).
Among the gradual-cessation group, 89.7\% (70/78) quarters and $84.0 \%(42 / 50)$ cows infected at D-O were classified as cured at CALV, whereas the remaining quarters $(10.3 \%)$ and cows $(16.0 \%)$ were classified as having a persistent infection. Of the 542 total quarters among the gradual-cessation cows, 33 new infections (6.1\%) in 29 cows $(20.0 \%)$ arose between D-O and CALV. Within the abrupt-cessation cows, 59 of 67 (88.1\%) of the infected quarters and 34 of $42(81.0 \%)$ infected cows at D-O cured by CALV, whereas 8 (11.9\%) quarter-level infections in 8 of 42 cows (19.0\%) persisted into the following lactation. Of the 544 total quarters dried off abruptly, 29 new infections (5.3\%) developed in 23 of 140 cows $(16.4 \%)$ between D-O and CALV. Proportions of quarters or cows that cured, had a persistent IMI, or acquired a new IMI were not statistically different between the 2 milk cessation groups $(P>0.435$ in any comparison).

IMI by Parity Group. When quarter-level infection status was compared between parity groups, several significant differences were observed (Table 4). Younger cows had a significantly greater proportion of quarters with IMI at D-O (mostly caused by minor pathogens), but a significantly higher portion of uninfected quarters at CALV than older cows.

Gradual Cessation Milk Leakage. Of the 145 gradual-cessation cows, $3(2.2 \%)$ were missing milk leakage observations during the once-daily milking period and were omitted from analysis. Another 16 quarters had contaminated or missing milk samples at PRE and were excluded from modeling, leaving 514 quarter-level observations representing 140 cows. Forty-one quarters (8.0\%) from 20 cows $(14.3 \%)$ were observed leaking at least once during the once-daily milking period. Thirty of the 41 quarters $(73.2 \%)$ from 15 cows were observed

Table 2. Descriptive statistics for cows dried off via gradual or abrupt cessation of milking at the end of lactation $^{1}$

\begin{tabular}{|c|c|c|}
\hline Item & $\begin{array}{l}\text { Gradual cessation } \\
\quad(\mathrm{n}=145)\end{array}$ & $\begin{array}{l}\text { Abrupt cessation } \\
\quad(\mathrm{n}=140)\end{array}$ \\
\hline DIM at dry-off ${ }^{2}$ & $328(3.7)$ & $353(6.2)$ \\
\hline Dry period length, ${ }^{2} \mathrm{~d}$ & $53(0.7)$ & $53(0.8)$ \\
\hline Lactation number ${ }^{2}$ & $1.8(0.1)$ & $1.9(0.1)$ \\
\hline \multicolumn{3}{|l|}{ Lactation, no. of cows } \\
\hline First lactation at dry-off & 74 & 68 \\
\hline Second lactation at dry-off & 42 & 37 \\
\hline Third and greater lactation at dry-off & 29 & 35 \\
\hline \multicolumn{3}{|l|}{ Breed, no. of cows } \\
\hline Holstein & 104 & 95 \\
\hline Jersey & 41 & 45 \\
\hline \multicolumn{3}{|l|}{ Internal teat sealant, no. of cows } \\
\hline Treated & 83 & 95 \\
\hline Not treated & 62 & 45 \\
\hline
\end{tabular}

${ }^{1}$ Gradual-cessation cows were milked once daily for the final week of lactation and then dried off. Abruptcessation cows kept their farm's normal milking schedule until dry-off.

${ }^{2}$ Values expressed as mean (SEM). 
Table 3. Microbiological culture results from quarter foremilk samples [no. (\%) of quarters positive] collected using aseptic technique 7 to $14 \mathrm{~d}$ before dry-off (PRE), at the final milking (D-O), and within $7 \mathrm{~d}$ of calving (CALV), presented by milk cessation group ${ }^{1,2}$

\begin{tabular}{|c|c|c|c|c|c|c|}
\hline \multirow[b]{2}{*}{ Bacterial species/group isolated } & \multicolumn{2}{|c|}{ PRE } & \multicolumn{2}{|c|}{$\mathrm{D}-\mathrm{O}^{3}$} & \multicolumn{2}{|c|}{ CALV } \\
\hline & $\begin{array}{c}\text { Gradual } \\
(\mathrm{n}=542)\end{array}$ & $\begin{array}{c}\text { Abrupt } \\
(\mathrm{n}=544)\end{array}$ & $\begin{array}{c}\text { Gradual } \\
(\mathrm{n}=542)\end{array}$ & $\begin{array}{c}\text { Abrupt } \\
(\mathrm{n}=544)\end{array}$ & $\begin{array}{c}\text { Gradual } \\
(\mathrm{n}=542)\end{array}$ & $\begin{array}{c}\text { Abrupt } \\
(\mathrm{n}=544)\end{array}$ \\
\hline Minor pathogens ${ }^{4}$ & $62(11.4)$ & $52(9.6)$ & $68(12.5)$ & $54(9.9)$ & $31(5.7)$ & $25(4.6)$ \\
\hline CNS & 59 & 51 & 65 & 53 & 25 & 24 \\
\hline Corynebacterium spp. & 3 & 1 & 3 & 1 & 6 & 1 \\
\hline Major pathogens ${ }^{4}$ & $12(2.2)$ & $14(2.6)$ & $11(2.0)$ & $16(2.9)$ & $14(2.6)$ & $13(2.4)$ \\
\hline Gram-negative spp. & 0 & 2 & 2 & 3 & 2 & 2 \\
\hline Other pathogens ${ }^{5}$ & 0 & 0 & 0 & 0 & 0 & 3 \\
\hline Mixed infections ${ }^{4}$ & $2(0.4)$ & $3(0.6)$ & $1(0.2)$ & 3 & $4(0.7)$ & $2(0.4)$ \\
\hline Contaminated samples & $9(1.7)$ & $12(2.2)$ & - & - & - & - \\
\hline Uninfected quarters & $454(83.8)$ & $465(85.5)$ & $464(85.6)$ & $477(87.7)$ & $501(92.4)$ & $508(93.4)$ \\
\hline
\end{tabular}

${ }^{1}$ Milk cessation groups included gradual-cessation cows (milked once daily for the final week of lactation) and abrupt-cessation cows (kept their farm's normal milking schedule until dry-off).

${ }^{2} \mathrm{~A}$ quarter was considered to have an IMI when 10 or more colonies per $0.01 \mathrm{~mL}$ of similar morphology were isolated, except for contagious major pathogens where isolation of $1 \mathrm{cfu} / 0.01 \mathrm{~mL}$ was considered an IMI.

${ }^{3}$ If cows had missing or contaminated D-O quarter samples, but had complete PRE data, then PRE culture results replaced D-O culture results for all 4 quarters of those cows.

${ }^{4}$ Pathogens causing mixed infections were also included under the respective pathogen category in the individual organism count.

${ }^{5}$ No Streptococcus agalactiae were isolated during the study.

leaking milk only once, and the other 11 quarters (26.8\%) of 5 cows were observed leaking on 2 separate days during the once-daily milking period. Three cows were marked as leaking from all 4 quarters because the individual quarter(s) leaking was (were) not readily apparent; all of these cows were observed leaking only once.

Milk Leakage After Dry-Off. One hundred seven cows (62 gradual cessation; 45 abrupt cessation) and 399 quarters (224 gradual cessation; 175 abrupt ces-

Table 4. Quarter-level IMI status at dry-off (D-O) and within $7 \mathrm{~d}$ of calving (CALV) by parity group (primiparous vs. multiparous; designated at dry-off $)^{1}$

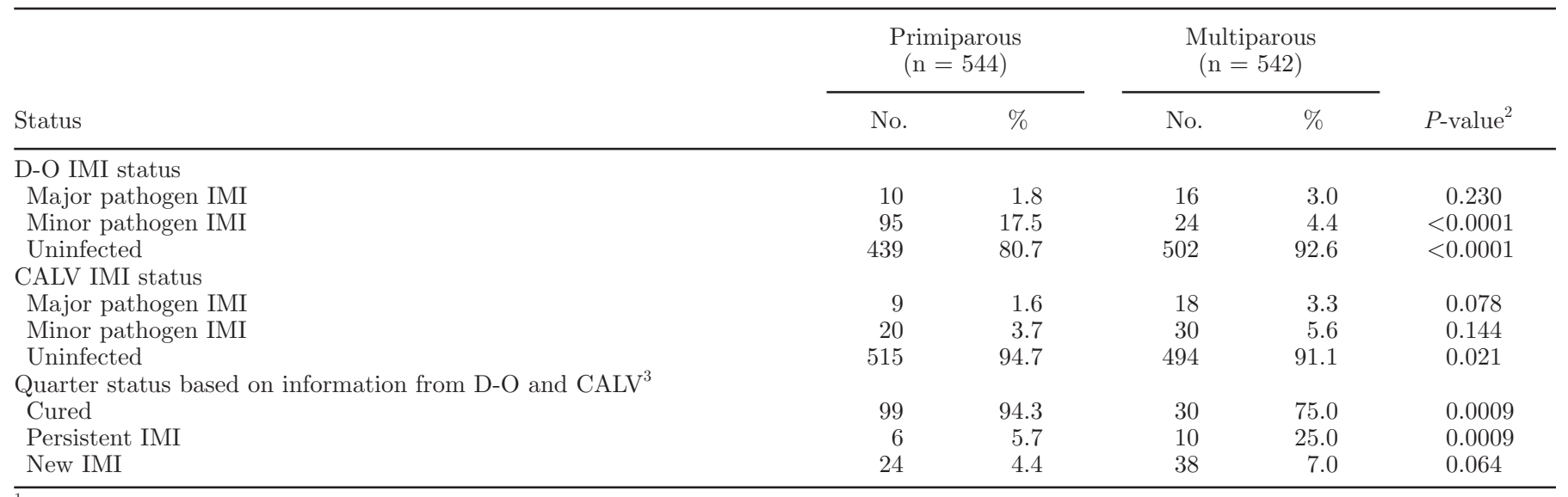

${ }^{1}$ Minor pathogens included CNS and Corynebacterium spp. All other isolates were considered major pathogens. Isolation of $>10$ colonies of similar morphology $(1,000 \mathrm{cfu} / \mathrm{mL})$ per quarter defined an IMI, except for contagious major pathogens, where isolation of $1 \mathrm{cfu} / 0.01 \mathrm{~mL}$ was considered an IMI.

${ }^{2} P$-values are based on 2-sample proportion test comparing quarter-level IMI status between primiparous and multiparous cows.

${ }^{3} \mathrm{~A}$ cure occurred when a specific pathogen causing an IMI at D-O was not isolated at CALV. New IMI at CALV was detected when an uninfected quarter at D-O had an IMI at CALV or when an infected quarter had a different pathogen isolated at CALV from the pathogen isolated at D-O. The presence of the same pathogen at D-O and at CALV was considered a persistent IMI. Cured and persistent IMI are presented as percentage of IMI at D-O. 
Table 5. Final logistic regression model for primiparous cows, explaining the association of milk cessation method and other factors with the odds of quarter-level IMI at calving (herd was included in the model as a random effect)

\begin{tabular}{|c|c|c|c|c|c|}
\hline Variable & Coefficient & Odds ratio $(\mathrm{OR})$ & \multicolumn{2}{|c|}{$95 \% \mathrm{CI}$ for $\mathrm{OR}$} & $P$-value \\
\hline \multicolumn{6}{|l|}{ 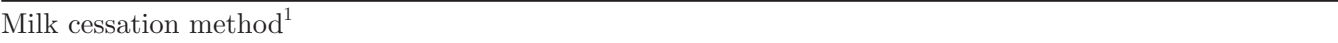 } \\
\hline Gradual & -1.25 & 0.29 & 0.12 & 0.68 & 0.005 \\
\hline Abrupt & Referent & 1 & - & - & \\
\hline Milk leakage after dry-off & & & & & 0.023 \\
\hline Leaking milk & 3.36 & 28.86 & 2.47 & 336.73 & 0.007 \\
\hline ITS used (not observed) ${ }^{2}$ & -0.37 & 0.69 & 0.10 & 4.61 & 0.703 \\
\hline No leakage & Referent & 1 & - & - & \\
\hline
\end{tabular}

${ }^{1}$ Gradual-cessation cows were milked once daily for the final week of lactation and then dried off. Abruptcessation cows kept their farm's normal milking schedule until dry-off.

${ }^{2}$ Cows treated with internal teat sealant (ITS) were not observed for milk leakage following dry-off.

sation) from one herd were observed for milk leakage after dry-off. Of the gradual-cessation cows, 12 quarters (5.4\%) from 10 cows $(16.1 \%)$ were observed leaking at least once after dry-off. Eight of these quarters $(66.7 \%)$ from 7 cows were seen leaking once, and 4 quarters (33.3\%) from 3 cows were observed leaking on 2 separate days after dry-off. Eight (4.6\%) abrupt-cessation quarters from 4 cows (8.9\%) were seen leaking after dry-off and all of these were observed leaking only once. Out of the leakage observations, only one cow from the abrupt-cessation group was marked as leaking from all 4 quarters because the individual quarter(s) leaking was (were) not readily apparent. All other leakage observations were made on actively leaking quarters that were identified individually. The proportion of quarters and cows observed leaking at least once after dry-off did not differ significantly $(P=0.719, P=0.271$, respectively $)$ between milk cessation groups.

\section{Models for IMI at Calving}

The initial full model investigating the association of milk cessation method with the odds of IMI at calving included parity group as a predictor. Milk yield at D-O was not significant $(P=0.715)$ when tested as the sole predictor of IMI at CALV and was not included when building the full model. Milk cessation method was not significant $(P=0.566)$ in the final full model, but the direction of the relationship suggested that gradual-cessation cows had lower odds of IMI at calving than abrupt-cessation cows (results not shown). Parity group at $\mathrm{D}-\mathrm{O}$ was significant $(P=0.019)$, and a highly significant interaction term between milk cessation method and parity group was revealed $(P=$ 0.0002). Thus, the final model investigating the effect of milk cessation on IMI at CALV was stratified by parity group at $\mathrm{D}-\mathrm{O}$. The final models for primiparous

Table 6. Final logistic regression model for multiparous cows explaining the association of milk cessation method and other factors with the odds of quarter-level IMI at calving (herd was included in the model as a random effect)

\begin{tabular}{|c|c|c|c|c|c|}
\hline Variable & Coefficient & Odds ratio (OR) & \multicolumn{2}{|c|}{$95 \%$ CI for OR } & $P$-value \\
\hline \multicolumn{6}{|l|}{ Milk cessation method $^{1}$} \\
\hline Gradual & 1.02 & 2.78 & 1.34 & 5.75 & 0.006 \\
\hline Abrupt $^{2}$ & Referent & 1 & - & - & \\
\hline D-O infection status ${ }^{2}$ & & & & & $<0.0001$ \\
\hline Minor pathogen IMI & 1.53 & 4.63 & 1.73 & 12.44 & 0.002 \\
\hline Major pathogen IMI & 2.28 & 9.81 & 2.94 & 32.66 & 0.0002 \\
\hline Noninfected & Referent & 1 & - & - & \\
\hline \multicolumn{6}{|l|}{ Milking frequency ${ }^{3}$} \\
\hline Twice daily & -1.22 & 0.29 & 0.13 & 0.65 & 0.003 \\
\hline Thrice daily & Referent & 1 & - & - & \\
\hline
\end{tabular}

${ }^{1}$ Gradual-cessation cows were milked once daily for the final week of lactation and then dried off. Abruptcessation cows kept their farm's normal milking schedule until dry-off.

${ }^{2}$ Quarter foremilk samples were collected using aseptic technique at the final milking (D-O). Minor pathogens included CNS and Corynebacterium spp. All other isolates were considered major pathogens. Isolation of $\geq 10$ colonies of similar morphology per quarter defined an IMI. Isolation of $>2$ colony morphologies was considered contamination, and contaminated samples were excluded.

${ }^{3}$ Milking frequency refers to the normal milking frequency during lactation, independent of milk cessation method. 
and multiparous cows are presented in Table 5 and Table 6 , respectively.

Among cows ending their first lactation, milk cessation method was significantly associated with the likelihood of IMI at CALV (Table 5). The odds of IMI at CALV for quarters dried off abruptly were 3.5 times higher than for quarters milked once daily for the final week of lactation. Quarters of primiparous cows observed leaking milk at least once after dry-off had 28.9 times higher odds of IMI at CALV than quarters of primiparous cows that were not observed leaking milk after dry-off. Intramammary infection status at D-O was not significantly associated with IMI status at CALV for primiparous cows $(P=0.309)$.

In contrast, quarters of multiparous cows milked once daily before dry-off had 2.8 times higher odds of IMI at CALV than quarters of abruptly dried-off multiparous cows (Table 6). Among multiparous cows, quarters infected by major pathogens at D-O had 9.8 times higher odds of being infected at CALV with any pathogen than quarters that were uninfected at D-O. Similarly, quarters of multiparous cows infected with minor pathogens at D-O had 4.6 times higher odds of calving with an IMI than quarters that were uninfected at D-O. The odds of IMI at CALV were 3.4 times higher for multiparous cows milked thrice daily during lactation compared with multiparous cows milked twice daily throughout lactation, independent of milk cessation method during the study.

Average daily milk yield at D-O was not found to be significantly associated with the risk of IMI at CALV $(P=0.653)$ for either parity group when adjusted for the milk cessation method. Season at D-O did not affect IMI status at CALV and was not a confounder. Due to management and barn restrictions in one herd, gradual-cessation cows went through the parlor at regular milking times when they were not milked. However, no differences in IMI status at CALV were seen between gradual-cessation cows that only went to the milking parlor once daily and those gradual-cessation cows that went through the milking parlor during every milking. The use of an ITS was not associated with the risk of IMI at CALV in this study. Days in milk at $\mathrm{D}-\mathrm{O}$ and the length of the dry period were not shown to affect the risk of IMI at calving. None of the above factors were shown to be confounders of the association of milk cessation method and quarter-level risk of IMI at CALV. When herd was included in the models as a fixed effect, it was a significant predictor of the outcome; however, the interaction term between herd and milk cessation method was not significant. In the final models, herd was accounted for by modeling it as a random effect.

\section{Models for Milk Leakage}

Gradual-Cessation Milk Leakage. Average daily milk yield before study intervention was forced into the model investigating milk leakage during once-daily milking. Although not significant, for every $4.5-\mathrm{kg}$ increase in milk yield at PRE above $18.1 \mathrm{~kg}$, the odds that a gradual cessation quarter would be observed leaking increased $31 \%$ [odds ratio $(\mathbf{O R})=1.31,95 \%$ CI: 0.91 to $1.89 ; P=0.149]$. Quarters of cows ending their third or greater lactation had 3.0 times greater odds of leaking milk during once-daily milking than quarters of cows ending their first or second lactation $(\mathrm{OR}=3.0,95 \%$ CI: 1.07 to $8.46 ; P=0.037)$. Additionally, quarters infected with any pathogen at PRE had 2.2 times higher odds of leaking during once-daily milking than quarters of cows that were uninfected at PRE (OR $=2.2,95 \%$ CI: 1.11 to $4.57 ; P=0.025)$. None of the other predictors were associated with milk leakage during once-daily milking, and no biologically relevant 2-way interactions were present between the main effects.

Milk Leakage After Dry-Off. Milk cessation method was forced into the model investigating whether a cow would be observed leaking milk following dryoff. Unexpectedly, cows milked once daily for the final week of lactation tended to have higher odds of being observed leaking milk following dry-off than cows that were dried off abruptly $(\mathrm{OR}=5.2,95 \%$ CI: 0.91 to 29.45; $P=0.062$ ). In addition, for every $4.5-\mathrm{kg}$ increase in milk yield at D-O above $18.1 \mathrm{~kg}$, the odds of being observed leaking milk increased 2.1 times $(\mathrm{OR}=2.1$, 95\% CI: 1.03 to $4.33 ; P=0.042$ ). Cows that ended their third or greater lactation had 6.0 times higher odds of leaking after dry-off than cows ending their first or second lactation $(\mathrm{OR}=6.0,95 \%$ CI: 1.83 to $19.93 ; P=$ 0.003). No other predictors were associated with milk leakage following dry-off and no significant biologically meaningful 2-way interactions between main effects were found.

\section{DISCUSSION}

The current study evaluated whether gradual cessation of milking before dry-off provided benefits to modern dairy cows by reducing milk yield before dryoff and reducing the risk of developing new IMI at calving. A once-daily milking frequency during the final week of lactation was chosen as the gradual-cessation method because this straightforward schedule would be relatively easy to implement and manage in herds and it had been found effective at reducing daily milk yield in a previous study (Oliver et al., 1990). A main result 
of the present study was that once-daily milking during the final week of lactation significantly decreased milk production before dry-off, on average by $33.4 \%$, without any alteration in the ration. The influence of milk cessation method with or without dietary changes on milk yield at the end of lactation and on IMI status at calving has been studied previously (Natzke et al., 1975; Oliver et al., 1990; Newman et al., 2010). Oncedaily milking for at least $3 \mathrm{~d}$ before dry-off reduced IMI at calving compared with abrupt cessation when no intramammary antimicrobial dry cow therapy was used (Natzke et al., 1975). The combination of once-daily milking during the final week of lactation and intramammary antimicrobial dry-cow therapy at dry-off was most beneficial to udder health (Oliver et al., 1990), whereas combining once-daily milking and a reduced energy ration during the final week of lactation resulted in the greatest reduction in milk yield before dry-off (Oliver et al., 1990). Changing the diet to a reduced energy ration alone has also been shown to reduce milk yield before dry-off and to reduce the risk of IMI during the dry period and at calving (Odensten et al., 2007).

A novel finding of the current study was that milk cessation method before dry-off affected the risk of developing IMI at calving differently for cows that ended their first lactation versus older cows. Gradual cessation of milking was beneficial to mammary health for cows ending their first lactation, but the opposite effect was observed among multiparous cows. To the best of our knowledge, this is the first study to report differing associations between milk cessation method and intramammary health status depending on parity group. Previous studies have shown differences between primiparous and multiparous cows relating to many aspects of animal health and production parameters (Fonseca et al., 1983; Wathes et al., 2007; Wittrock et al., 2011). In addition, udder health has been shown to vary depending on parity group. Multiparous cows had more IMI during the dry period, more persisting IMI, and more clinical cases of mastitis at calving compared with primiparous cows (Neave et al., 1950), and the results of the current study are in accordance with this. The prevalence of IMI of environmental origin during the dry period and following parturition has also been reported to be greater among higher parity cows (Ward and Schultz, 1974; Oliver and Mitchell, 1983; Smith et al., 1985). In the current study, we did not intend to investigate parity-related differences but identified this as a potential area for further research regarding why different parity groups had opposing IMI status responses at calving to once-daily milking before dryoff. In the current study, older cows were also more likely to leak milk both during the week of reduced milking frequency as well as after dry-off, regardless of the milk cessation method; this may be related to the integrity of the teat end (Klaas et al., 2005) and could explain some of the observed differences between the parity groups.

Overall, the most common pathogens isolated at both dry-off and calving were CNS, in agreement with previous reports (Petzer et al., 2009; Gundelach et al., 2011). When IMI were compared between parity groups, cows ending their first lactation had a significantly greater proportion of quarter-level IMI at D-O (mostly caused by minor pathogens) but a significantly lower proportion of infected quarters at CALV than older cows. This is likely due to significantly higher cure rate over the dry period and fewer persistent and new IMI among younger cows than older cows, in agreement with previous studies (Browning et al., 1994; Taponen et al., 2006), which also reported higher cure rates among younger cows. When persistent IMI in quarters were considered, over half of the quarters were infected with CNS. However, because no speciation was performed, it is not known whether these were truly persistent infections or cures and new infections with different species of CNS.

Based on the sample size calculation performed before the study, an ample number of observations was collected, but no significant differences in IMI prevalence at calving between the study groups were observed. This suggests that there truly was no difference in the prevalence of IMI when data from all cows were combined; however, significant differences were observed when data were stratified by parity group. The IMI prevalence at calving was only $7 \%$ for each milk cessation group, which was lower than expected and previously reported (Petzer et al., 2009; Gundelach et al., 2011). The low IMI prevalence could be because the IMI definition used in the current study provided near-perfect specificity but low sensitivity, which means some quarters that had an IMI may have erroneously been classified as uninfected (Lopez-Benavides et al., 2012). When the goal is identification of as many IMI as possible, the growth of a single colony from 0.01 $\mathrm{mL}$ of milk should be used to designate the presence of an IMI, as this has a more balanced sensitivity and specificity (Dohoo et al., 2011; Lopez-Benavides et al., 2012). The CNS are part of the normal teat skin flora and have frequently been reported to be the most common organisms isolated from cows at dry-off and calving (Matthews et al., 1992; Taponen et al., 2008; Vanderhaeghen et al., 2015). Thus, finding only one colony of CNS or environmental organisms per 0.01 $\mathrm{mL}$ could be due to contamination from the teat skin, not an indication of a true IMI. Thus, a cut-off of $>1$ 
$\mathrm{cfu} / 0.01 \mathrm{~mL}$ was chosen for all other pathogens except for contagious major pathogens. The IMI definition used in the current study was suggested as a suitable definition when only a single milk sample was used to determine presence of an IMI (Andersen et al., 2010). The lower cut-off for contagious major pathogens was chosen to ensure as high sensitivity as possible for these organisms. However, no Staph. aureus-positive quarter samples had colony counts as low as $1 \mathrm{cfu} / 0.01 \mathrm{~mL}$ and no IMI would have been missed with the cut-off of $\geq 10 \mathrm{cfu} / \mathrm{mL}$. This is consistent with results of Walker et al. (2011), who reported that Staph. aureus are shed consistently and in high levels in naturally occurring infections.

Despite numerous studies reporting an increasing risk of IMI at calving with increasing milk yield level at dryoff (Oliver et al., 1990; Dingwell et al., 2004; RajalaSchultz et al., 2005), the current study did not find an association between milk yield at the time of dry-off and prevalence of IMI with any pathogen at calving. This is in agreement with the study by Natzke et al. (1975), who reported that milk production level at the time of dry-off had no significant effect on the rate of new IMI. The presence of conflicting data indicates that further research in this area is needed. However, cowto-cow variation and herd-to-herd variation are known to exist for many factors associated with dairy cow and herd management. Milk yield before dry-off and its relationship to IMI status at calving could depend on the interrelationship between cows, management practices, facilities, and the environment on individual farms. In the current study, when herd was included as a fixed effect in the models, the interaction term between herd and milk cessation method was not significant, suggesting that the effect of dry-off method did not differ between herds. However, a blanket recommendation for optimal milk production level at the time of dry-off that is beneficial for all cows in all herds may not exist.

Despite a significant decrease in daily milk yield for cows in the gradual-cessation group, the odds of milk leakage after dry-off tended unexpectedly to be greater in quarters of gradual-cessation cows than in quarters of abrupt-cessation cows. A previous study reported $30 \%$ of cows to be leaking milk following dry-off, despite being fed a reduced energy ration and following an intermittent milking schedule for the final $2 \mathrm{wk}$ of lactation (Schukken et al., 1993). Tucker et al. (2009) reported no differences in milk leakage following dryoff between treatment groups differentiated by milking frequency during the final week of lactation. A more recent study reported that abrupt-cessation cows leaked milk more frequently than cows that were dried off via gradual cessation but that there was no difference in milk yield before dry-off between cows that did or did not leak milk (Zobel et al., 2013). A study examining risk factors for milk leakage during lactation indicated that random herd effects accounted for only $10 \%$ of the total variation on the occurrence of milk leakage (Klaas et al., 2005). These studies suggest that factors beyond the milk cessation method are likely related to the risk for milk leakage following dry-off.

In the current study, milk leakage following dry-off was not monitored in herds that used ITS; however, it has been reported that cows may leak milk even after infusion of ITS into mammary quarters (Zobel et al., 2013). Milk leakage observations after dry-off from all cows, irrespective of ITS usage, could provide better insight into the association of milk leakage after dry-off and IMI at calving, and would provide a better understanding regarding the occurrence of milk leakage around the time of dry-off. Thus, further research is encouraged to monitor milk leakage following dry-off, regardless of ITS usage. Additionally, this study was conducted in multiple private dairy facilities, not in research herds. This was a challenge, because the investigators could not require any management changes (other than the alteration in milk cessation method for some of the study cows) due to the risk of losing potential participants. The milk cessation alterations alone deterred some producers from participating due to concerns about facility and labor limitations. Despite the challenges and limitations associated with this large field study, significant associations were revealed.

\section{CONCLUSIONS}

Gradual cessation of milking successfully decreased milk production before dry-off, but milk yield before dry-off did not have a significant effect on overall IMI prevalence at calving. However, gradual cessation of milking affected cows ending their first lactation and older cows differently. Quarters of primiparous cows dried off via gradual cessation were significantly less likely to have an IMI at the time of calving compared with quarters of primiparous cows that were dried off abruptly. In contrast, quarters of cows ending their second or greater lactation and dried off by gradual cessation had significantly higher odds of IMI at calving than quarters of cows dried off abruptly. These results indicate that implementation of differing management practices near dry-off for different parity groups within a farm may be beneficial to mammary health across the herd.

\section{ACKNOWLEDGMENTS}

The investigators thank the producers and herd managers for their participation in the study, as well as the 
numerous colleagues who helped with sample collection during the study. This project was supported by Agriculture and Food Research Initiative Competitive Grant no. 2012-67015-30203 from the USDA National Institute of Food and Agriculture (Washington, DC).

\section{REFERENCES}

Andersen, S., I. R. Dohoo, R. Olde Riekerink, H. Stryhn, and Mastitis Research Workers' Conference. 2010. Diagnosing intramammary infections: Evaluating expert opinions on the definition of intramammary infection using conjoint analysis. J. Dairy Sci. 93:2966-2975.

Bradley, A. J., and M. J. Green. 2000. A study of the incidence and significance of intramammary enterobacterial infections acquired during the dry period. J. Dairy Sci. 83:1957-1965.

Bradley, A. J., and M. J. Green. 2001. A study of the incidence and significance of Gram-positive infections acquired during the dry period under UK field conditions. Pages 185-186 in Proc. 40th Annu. Mtg. Natl. Mastitis Counc., Reno, NV. Natl. Mastitis Counc., Inc., Madison, WI.

Bradley, A. J., and M. J. Green. 2004. The importance of the nonlactating period in the epidemiology of intramammary infection and strategies for prevention. Vet. Clin. North Am. Food Anim. Pract. $20: 547-568$.

Browning, J. W., G. A. Mein, P. Brightling, T. J. Nichols, and M. Barton. 1994. Strategies for mastitis control: Dry cow therapy and culling. Aust. Vet. J. 71:179-181.

Dingwell, R. T., K. E. Leslie, Y. H. Schukken, J. M. Sargeant, L. L. Timms, T. F. Duffield, G. P. Keefe, D. F. Kelton, K. D. Lissemore, and J. Conklin. 2004. Association of cow and quarter-level factors at drying-off with new intramammary infections during the dry period. Prev. Vet. Med. 63:75-89.

Dohoo, I. R., J. Smith, S. Andersen, D. F. Kelton, S. Godden, and Mastitis Research Workers' Conference. 2011. Diagnosing intramammary infections: Evaluation of definitions based on a single milk sample. J. Dairy Sci. 94:250-261.

Eberhart, R. J. 1986. Management of dry cows to reduce mastitis. J. Dairy Sci. 69:1721-1732.

Elbers, A. R. W., J. D. Miltenburg, D. de Lange, A. P. P. Crauwels, H. W. Barkema, and Y. H. Schukken. 1998. Risk factors for clinical mastitis in a random sample of dairy herds from the southern part of the Netherlands. J. Dairy Sci. 81:420-426.

Espe, D. L., and V. R. Smith. 1952. Secretion of Milk. Pages 263-264. Iowa State College Press, Ames.

Fonseca, F. A., J. H. Britt, B. T. McDaniel, J. C. Wilk, and A. H. Rakes. 1983. Reproductive traits of Holsteins and Jerseys. Effects of age, milk yield, and clinical abnormalities on involution of cervix and uterus, ovulation, estrous cycles, detection of estrus, conception rate, and days open. J. Dairy Sci. 66:1128-1147.

Gundelach, Y., E. Kalscheuer, H. Hamann, and M. Hoedemaker. 2011. Risk factors associated with bacteriological cure, new infection, and incidence of clinical mastitis after dry cow therapy with three different antibiotics. J. Vet. Sci. 12:227-233.

Klaas, I. C., C. Enevoldsen, A. K. Ersboll, and U. Tolle. 2005. Cowrelated risk factors for milk leakage. J. Dairy Sci. 88:128-136.

Lombard, J. E., G. Zobel, A. E. Adams, C. P. Fossler, C. B. Shivley, N. J. Urie, and C. A. Kopral. 2015. Dry-off procedures on US dairy operations. J. Dairy Sci. 98(E-Suppl. 2):238. (Abstr.)

Lopez-Benavides, M., I. Dohoo, D. Scholl, J. Middleton, and R. Perez. 2012. Interpreting bacteriological culture results to diagnose bovine intramammary infections. NMC Research Committee Report. National Mastitis Council Inc., Madison, WI.

Matthews, K. R., R. J. Harmon, and B. E. Langlois. 1992. Prevalence of Staphylococcus species during the periparturient period in primiparous and multiparous cows. J. Dairy Sci. 75:1835-1839.

Natzke, R. P., R. W. Everett, and D. R. Bray. 1975. Effect of drying off practices on mastitis infection. J. Dairy Sci. 58:1828-1835.
Natzke, R. P., R. W. Everett, R. S. Guthrie, J. F. Keown, A. M. Meek, W. G. Merrill, S. J. Roberts, and G. H. Schmidt. 1972. Mastitis control program: Effect on milk production. J. Dairy Sci. $55: 1256-1260$.

Neave, F. K., F. H. Dodd, and E. Henriques. 1950. Udder infections in the dry period. I. J. Dairy Res. 17:37-49.

Newman, K. A., P. J. Rajala-Schultz, F. J. DeGraves, and J. Lakritz. 2010. Association of milk yield and infection status at dry-off with intramammary infections at subsequent calving. J. Dairy Res. 77:99-106.

NMC (National Mastitis Council). 2004. Microbial Procedures for the Diagnosis of Bovine Udder Infection and Determination of Milk Quality. National Mastitis Council Inc., Madison, WI.

Odensten, M. O., B. Berglund, K. Persson Waller, and K. Holtenius. 2007. Metabolism and udder health at dry-off in cows of different breeds and production levels. J. Dairy Sci. 90:1417-1428.

Oliver, J., F. H. Dodd, and F. K. Neave. 1956a. Udder infections in the dry period. III. The method of drying-off cows in the dry period. J. Dairy Res. 23:197-203.

Oliver, J., F. H. Dodd, and F. K. Neave. 1956b. Udder infections in the dry period. IV. The relationship between the new infection rate in the early dry period and the daily milk yield at drying-off when lactation was ended by either intermittent or abrupt cessation of milking. J. Dairy Res. 23:204-211.

Oliver, S. P., and B. A. Mitchell. 1983. Susceptibility of bovine mammary gland to infections during the dry period. J. Dairy Sci 66:1162-1166.

Oliver, S. P., E. P. Shull, and H. H. Dowlen. 1990. Influence of different methods of milk cessation on intramammary infections during the peripartum period. Pages 92-97 in Proc. Int. Symp. Bovine Mastitis, Indianapolis, IN. National Mastitis Council, Arlington, VA.

Petzer, I.-M., D. C. Lourens, T. J. van der Schans, J. C. Watermeyer, R. van Reenen, G. H. Rautenbach, and P. Thompson. 2009. Intramammary infection rate during the dry period in cows that received blanket dry cow therapy: Efficacy of 6 different dry-cow intramammary antimicrobial products. J. S. Afr. Vet. Assoc. 80:23-30.

Rajala-Schultz, P. J., J. S. Hogan, and K. L. Smith. 2005. Association between milk yield at dry-off and probability of intramammary infections at calving. J. Dairy Sci. 88:577-579.

Rovai, M., M. T. Kollmann, and R. M. Bruckmaier. 2007. Incontinentia lactis: Physiology and anatomy conducive to milk leakage in dairy cows. J. Dairy Sci. 90:682-690.

Schukken, Y. H., F. J. Grommers, D. Vandegeer, H. N. Erb, and A. Brand. 1990. Risk factors for clinical mastitis in herds with a low bulk milk somatic cell count. 1. The data and risk factors for all cases. J. Dairy Sci. 73:3463-3471.

Schukken, Y. H., J. Vanvliet, D. Vandegeer, and F. J. Grommers. 1993. A randomized blind trial on dry cow antibiotic infusion in a low somatic cell count herd. J. Dairy Sci. 76:2925-2930.

Seegers, H., C. Fourichon, and F. Beaudeau. 2003. Production effects related to mastitis and mastitis economics in dairy cattle herds. Vet. Res. 34:475-491.

Smith, K. L., D. A. Todhunter, and P. S. Schoenberger. 1985. Environmental pathogens and intramammary infection during the dry period. J. Dairy Sci. 68:402-417.

Taponen, S., J. Bjorkroth, and S. Pyörälä. 2008. Coagulase-negative staphylococci isolated from bovine extramammary sites and intramammary infections in a single dairy herd. J. Dairy Res. 75:422429.

Taponen, S., H. Simojoki, M. Haveri, H. D. Larsen, and S. Pyörälä. 2006. Clinical characteristics and persistence of bovine mastitis caused by different species of coagulase-negative staphylococci identified with API or AFLP. Vet Microbiol. 115:199-207.

Tucker, C. B., S. J. Lacy-Hulbert, and J. R. Webster. 2009. Effect of milking frequency and feeding level before and after dry off on dairy cattle behavior and udder characteristics. J. Dairy Sci. 92:3194-3203.

Vanderhaeghen, W., S. Piepers, F. Leroy, E. Van Coillie, F. Haesebrouck, and S. De Vliegher. 2015. Identification, typing, ecology and 
epidemiology of coagulase negative staphylococci associated with ruminants. Vet. J. 203:44-51.

Waage, S., S. A. Odegaard, A. Lund, S. Brattgjerd, and T. Rothe. 2001. Case-control study of risk factors for clinical mastitis in postpartum dairy heifers. J. Dairy Sci. 84:392-399.

Walker, J. B., P. J. Rajala-Schultz, W. L. Walker, J. L. Mathews, W. A. Gebreyes, and F. J. DeGraves. 2011. Variation in daily shedding patterns of Staphylococcus aureus in naturally occurring intramammary infections. J. Vet. Diagn. Invest. 23:1114-1122.

Ward, G. E., and L. H. Schultz. 1974. Incidence and control of mastitis during the dry period. J. Dairy Sci. 57:1341-1349.

Wathes, D. C., Z. Cheng, N. Bourne, V. J. Taylor, M. P. Coffey, and S. Brotherstone. 2007. Differences between primiparous and multiparous dairy cows in the inter-relationships between metabolic traits, milk yield and body condition score in the periparturient period. Domest. Anim. Endocrinol. 33:203-225.
Wayne, R., C. H. Eckles, and W. E. Peterson. 1933. Drying up cows and the effect of different methods upon milk production. J. Dairy Sci. 16:69-78.

Wayne, R., and H. Macy. 1933. The effect of various methods for drying up cows on the bacterial and cell content of milk. J. Dairy Sci 16:79-91.

Wittrock, J. M., K. L. Proudfoot, D. M. Weary, and M. A. G. von Keyserlingk. 2011. Short communication: Metritis affects milk production and cull rate of Holstein multiparous and primiparous dairy cows differently. J. Dairy Sci. 94:2408-2412.

Zobel, G., K. Leslie, D. M. Weary, and M. A. G. von Keyserlingk. 2013. Gradual cessation of milking reduces milk leakage and motivation to be milked in dairy cows at dry-off. J. Dairy Sci. 96:5064-5071. 